\title{
The Crypt: Probing the Obscure Administration of Cultural Memory
}

\author{
JOHAN REDIN ${ }^{1}$ \\ Södertörn University \\ PETER JACKSON \\ University of Stockholm
}

\begin{abstract}
The prescribed means to engage with the past through a variety of culturally upheld techniques is receiving wider attention within the humanities today. This is partly due to the growing field of so-called 'cultural memory studies'. Religion is typically evoked in these circumstances as an exemplary entry into processes of long-term cultural mediation, and the different interests permeating the maintenance and obfuscation of a time-honoured past. The article is devoted to a concept that has attracted comparatively little attention among students of cultural memory: the crypt and its various analogies to the question of remembrance without memory.
\end{abstract}

Keywords: cultural memory, cultural forgetting, repression, historical representation, museum, mythology

\section{Entering the Crypt}

A few years ago the authors of this essay visited the remarkable Bamberger Dom, a northern Bavarian church founded in the early twelfth century. The size of the Dome is as impressive as its astonishing interior. We suddenly noticed a candlelit staircase leading down to a small chamber, hosting a illuminated box containing deformed human remains. The pieces were apparently relics, and in that sense hardly something shocking or extraordinary. It was rather the location and the atmosphere that caused a perplexing feeling: the forward staircase, the welcoming light, and then the scenery

1 Johan Redin's contribution was supported by the Swedish research program Time, Memory and Representation: A Multidisciplinary Program on Transformations in Historical Consciousness, based at Södertörn University and funded by the Riksbankens Jubileumsfond. 
of something exhibited but not revealed or reflected. This was not just an ordinary tomb or burial chamber.

We had reached the secret heart of the church: the crypt-a remote space, enclosed, yet with open doors. The monumental building held a hidden yet accessible space deep within its interior structure, suggesting a cultural counterpart of suppressed memories, of events and experiences that are both remembered and forgotten: remembered in the sense that they are still preserved, but forgotten in the sense that they are displaced or suspended. The crypt of the Bamberger Dom still serves this double interest, in that it simultaneously engages the passive and active side of memory, as remembrance without memory. In the following pages we endeavour to develop this notion further, leaving the Bamberger Dom behind as a preliminary example and point of departure.

First of all, the simultaneous engagement of passive and active memory should not be taken metaphorically. It extends into numerous dimensions of cultural practice - not only those of religion - that make it complex in nature and obscure in its mechanisms and procedures. Mechanisms of preservation and suspension are pre-eminently at work in western societies through the more or less unreflected means by which official institutions, monuments, and other public agencies seem to preserve and administer the past, yet the necessity is present in any culture that symbolically handles its past. In our society memory is active in two fundamental ways: 1) as storage, be it immaterial or material, such as idioms, customs, museums, archives, libraries, safeguarded environments, etc; and 2) as continuous causes of evolvement (not necessarily implying advancement), a moving forward through a constant relation to a past, the contact between generations, shared beliefs, the conflict between obligation and innovation, etc. But might there not also be such a thing as a culturally repressed past? Might there not also be features of the past that lie open like purloined letters - within tradition, but never fully recognized?

\section{Cultural Memory in Context}

Before discussing the features of cultural forgetting and the figure of repression, we must turn to the question of cultural memory. In the 1920s the French sociologist Maurice Halbwachs, a student of Henri Bergson and Émile Durkheim, laid the ground work for the concept of a 'collective memory' 
(mémoire collective). ${ }^{2}$ Individual memories, Halbwachs argues, depend entirely on the existence of group memories and the given social conditions of the individual (Halbwachs 1992, 52 f.). Not that a certain group needs to share exactly the same set of remembered events or experiences, but that individual memories are formed, or 'framed', according to the collective way of generating identity (with regard to family, religion, class, city, region, nation, etc). Strongly dependent on the Durkheimian view of collectivity and social laws, Halbwachs limited the analysis to the dimension of social temporality and the shared past as the co-existence of different collective memories and modes of behavior.

Encouraged by the work of Halbwachs, and contributing to its revival in recent years, the Egyptologist Jan Assmann and the literary scholar Aleida Assmann have opened up the way for a wider and more comprehensive approach to memory and culture. ${ }^{3}$ The focus has shifted to the concept of 'cultural memory' as such, defined in terms of both its correspondence with and its delimitation from everyday 'communicative memory' (J. Assmann 1999a, 48ff). The latter is the reciprocal sharing of thoughts, feelings and knowledge within a shared past, assuming a cultural identity in a relatively narrow relationship to the preceding generations (J. Assmann 1999a, 35ff). Characteristic of communicative memory is its delimited time-span of two generations (roughly eighty to perhaps a hundred years); what happens beyond this loses the social framework of 'presentness' and is detached into history rather than belonging to memory. This is why Halbwachs, who insisted on the distinction between memory and history, did not take the mémoire collective further than this horizon.

It is notoriously difficult to pin down or delineate a concept of cultural memory, not only because of its scope, but also because memory is inseparable from forgetting. Cultural memory is neither just everyday reflective memory nor proper historical objectification. But this does not entail that it is useless or impossible to try to grasp its essence by interdisciplinary approaches to culture as such. Cultural memory is distant from the everyday, yet always kept alive as cultural formations (texts, rituals, monuments) as well as institutional communication (recitation, practice, observance) (J.

2 See Maurice Halbwachs, Les cadres sociaux de la mémoire (Paris 1925), La topographie légendaire des évangelies en terre sainte (Paris 1941) and La mémoire collective (published posthumously in 1950). A translation of the key texts is available in Halbwachs (1992).

3 Beginning in Heidelberg in the late 1970s by the initiation of interdisciplinary workshops on 'the archaeology of literary communication'. Hitherto thirteen edited volumes have been published in the series Beiträge zur Archäologie der literarischen Kommunikation by Wilhelm Fink Verlag; see especially the first volume (A. Assmann \& J. Assmann 1983). 
Assmann 1995, 129). By combining an anthropological approach with the study of the very techniques of memory, which includes its classical ars memorativa as well as its particular externalization in writing, symbols, images, etc, cultural memory can be distinguished as the often unconscious formulas that tend to structure the accumulation and organization of the past into prototypical models of distributive power and behavior, the growth of canons and the consideration of sacred texts, the maintenance of traditions, the formation of archives, etc. ${ }^{4} \mathrm{~A}$ sort of footnote to the comprehensive survey of cultural memory systems, Jan Assmann's essay ‘Krypta - Bewahrte und verdrängte Vergangenheit' aims towards a rather overlooked aspect of this empirical framework (J. Assmann 1999b). He envisions the crypt as one of those places rarely entered, but nonetheless forming a constitutive part of cultural memory's architectural setting. Without relying too much on the specific conditions of Assmann's paper - written a propos the works of the French artists Anne and Patrick Poirier - we wish to take the opportunity of proceeding experimentally and heuristically with the 'crypt' as an analytical matrix. Where does it lead us and by what means does it allow us to bring new or unforeseen aspects of cultural memory into light?

When we think of religion, especially in its etymological sense as a relegio (a 're-reading' or 're-collection'), memory is crucial (Benveniste 1969, $265 \mathrm{ff}$.). Nevertheless, the factuality of the crypt also suggests a culture of encryption, mirroring an important aspect of forgetting as an essential agent. While there are many established scholarly ways to investigate 'how societies remember' by studying collective processes, techniques, and traditions (Connerton 1989; Fentress \& Wickham 1992), much less attention has been paid to the means whereby a society forgets by unconsciously remembering its past. ${ }^{5}$ Traumatization is a regular example of a collective wound, reaching for recovery through erasure or the urge to 'move on'. Since the object of remembrance (and forgetting) is rejected, this process is always related to active forgetting. In order to clarify these issues, we need to investigate the notion of the crypt further, but we also need to consider the process that enable us to track down and identify the crypt as a partly hidden space within society. In order for objects and data to become integrated into (and detached from) a crypt, they must undergo certain processes of encryption

4 This is the typology of 'storage' (Speicherplatz) that does not need to be physical or even representational, yet always in accordance with temporality (see A. Assmann 1999).

5 One intriguing study, following the system analysis of Niklas Luhmann, and thus very different from ours, is Espositio (2002). See also Connerton (2009) although his focus is rather on temporality and place in (post)modern society. 
and decryption. There must be mechanisms at work within society by means of which objects and data turn into something distinct from what they used to be (encryption), but still leaving enough traces on their surface of appearance to make the transformation at least partly reversible (decryption). In other words, our purpose here is not to encode the crypt's architectonic setting or liturgical strategy, but rather to link the context of religion and memory to a broader cultural analysis that reaches for the deeper dimensions of cultural memory.

\section{Tales from the Crypt}

The word 'crypt' originates from the Greek adjective kruptós, kruptê ('hidden, secret') via the Latin noun crypta. While the Greek term covers a wide range of meanings, such as persons in disguise, trenches covered and concealed or deep-seated ulcers, it is the specific sense of the Latin noun crypta ('concealed underground passage or vault') that defines the modern usage of the term, namely a chamber or vault beneath the main floor of a church (OED, s.v.). Even if the specific sense of the term evokes the crypt as a particular kind of hidden space, the history of this territorial underground suggests that it is more than this. The crypt is also a space that hides something, a space that shelters another crypt within itself.

Let us clarify this statement with an example from Late Antiquity. It is a well-known fact that Christian churches often were erected above the remains of pagan temples, not least the kind of underground, cave-like shrines known as mithrea. The mysteries of the god Mithras had flourished alongside Christianity for more than three centuries when the Christian emperor Theodosius I, towards the end of the fourth century, decided to eradicate all forms of pagan worship from the Roman Empire (Clauss 1990, 40f). The rituals and soteriological teachings of Mithraism shared several features with those of Christianity, and must have appeared particularly intimidating to Christian officials. On the other hand, certain focal aspects of the cult inside the mithrea, such as the representation of Mithras sacrificing a bull with a dagger (the so-called tauroctony), clearly indicated a site of pagan worship. According to legends about the third-century martyr St. Saturninus, the alleged first bishop of Toulouse and apostle of the Gauls, a church was erected on the place of his martyrdom. Saturninus had been condemned by the pagan priests in the city when he refused to sacrifice to their gods. A rope was tied to his feet and a bull dragged him about the town until the rope broke. Two pious Christian women gathered his remains and 
buried them in a deep ditch, not to be profaned by pagans. The so-called 'church of the Taur' (the church of the bull), today's Notre Dame du Taur, was erected where the bull stopped. In light of the fact that many mithrea seem to have been converted into Christian crypts, it is tempting to read the legend of Saturninus as an allegorical inversion of the myth that highlights the iconographic universe of Mithraism. Instead of killing the bull, Saturninus is killed by it, yet his sacrificial death marks the mimetic victory of Christ and Christian worship at a site of old idolatry and superstition.

We cannot know for sure that the church of the Taur was erected above an old mithraeum, nor that the legend of Saturninus is a catechetical inversion of the pagan cults that once took place there. Nevertheless, we find such a host of examples of similar processes in other areas during other periods that it makes perfect sense to use the legend of Saturninus as a 'pre-text' to the kind of strategies of cultural memory that we address in this essay. It is difficult to imagine a situation in medieval Europe where Christian beliefs were disguised as central aspects of pagan worship. Yet there are numerous examples of the opposite phenomenon.

The hybridization of Christian and pre-Christian elements were constantly at work in the mutual neutralization and exploitation (remedy or expiatio) of pagan elements from top down on ecclesiastical or clerical initiatives. For example, a systematic enactment of such strategies is sanctioned by a paragraph in Codex Theodosianus (xvi.10.25), which recommends the destruction and transformation of pagan sanctuaries through the sign of the cross (Hanson 1978, 263). There are also examples of an encapsulation of such elements from bottom up grounded in folklore, popular medicine, and vernacular religiosity. A variant of the pagan so-called 'Second Merseburg Incantation' (around $750 \mathrm{CE}$ ) from a witch trial in Stavanger in 1685 clearly illustrates how oral traditions, although deeply rooted in pre-Christian medical practice, could incorporate Christian elements without giving up the original theme or wording: 'Our Lord Jesus rode on over the dry heath, the precious joint was torn. Our Lord Jesus stepped down, and said: bone in bone, marrow in marrow, blood in blood, skin in skin, flesh in flesh. ${ }^{6}$ The protagonists in the much earlier German Merseburg Incantation are still pagan gods and goddesses (Phol, Uuodan, Sinthgunt, Sunna, Friia and Volla). When such layered domains of culture simultaneously conceal and promote each other, they are caught within an uncertain division of power.

6 . 'Vaar Herre Jesus reid yver turre heid, det rinast i den dyraste led. Vaar Herre Jesus han steig sjölv av, og sagde: bein i bein, marg i marg, blod i blod, hud i hud og kjöt i kjöt.' See Kuhn (1864). 
A society does not merely administer its own past by means of selectively highlighting that which is to be remembered, it also secretly remembers and draws nourishment from that which is officially forgotten.

\section{Psychological Dimensions of the Crypt}

While this kind of handling never reaches the level of reflective action (or intention), it should still be understood as active in a certain sense. It is like an entity from the past that is not necessarily haunting, but still operating in the sense that it is not fully exceeded or healed. If we wish apprehend the possible links between collective and individual forms of encryption, not least the extent to which the operative degree of such processes depend on the context of encryption, it may seem obvious to consider such processes in analogy to Freud's theory of repression. Freud saw repression as a dialectic between suffering and desire, resulting in certain unconscious actions that remain in control (made apparent) precisely by being hidden. The causes are often traumatic experiences, turning a certain kind of action or event into permanence by trying to overcome it by forgetting.

Considering the vast impact of psychoanalysis on cultural theory, turning Freudian repression into cultural theory would, in other words, seem a tempting suggestion. Nevertheless, the Hungarian psychoanalysts Nicolas Abraham and Maria Torok's notion of a cryptonymie appears more fruitful in this regard. Their radical reinterpretation of the repression process was only partly developed in relation to Freud. Through a redirection of Sándor Ferenczi's definition of 'incorporation' and 'introjection', Abraham and Torok aim at a psychic topology, a kind of architecture of the unconsciousness (Abraham \& Torok 1994, 125-38). In the process of love or mourning, an introjection is an objectification of this other person that at the same time is a part of oneself. Love or mourning is therefore directed as much at oneself as at the person loved or lost. Incorporation, on the other hand, is a failed introjection, in the sense that crucial emotions (such as love, desire, or mourning) have created a blockage and ultimately a refusal. Something is locked in, isolated, and eventually erected by its total interiorization - it has become a crypt (Derrida 1986, xvi). This would be something like a 'live burial', and this haunting, ghostly crypt possesses all the features of a regular introjective process (i.e. sustaining its subsequent desires), although it reaches a secluded, hidden space. The crypt will thus continue to instruct as 'a special kind of unconscious' that is not altogether autonomous. Like a kernel within a shell, it is conscious and unconscious at the same time: in other words, 'conscious of itself and unconscious of the realm "outside the crypt"' (Abraham \& Torok 1986, 80). 


\section{Representational Dimensions of the Crypt}

Abraham and Torok's theories of the cryptic incorporation correspond to the very tension between memory and forgetfulness as a 'deep dimension of cultural memory' (J. Assmann 1999b, 83-99). An aspect of this dimension is the complexity as to how essential elements of cultural memory become present without revealing their origin, and thus almost impossible to pin down in their derivation. In the case of psychoanalysis it is always painful experiences that cause the refusal that results in the encryption of the introjection, but it does not need to be this dramatic when we turn to a historical process or the bearings of cultural memory. There are features of memory that are transferred and repeated without awareness of the context. For example, certain idioms can travel for many generations and become totally detached from their original meaning but still continue to 'make sense' in ordinary language use, just as symbols and even artifacts can change meaning and use several times over a long period of time.

Cultural practice and products seem to run in parallel, always in communication but not always in coherence. We repeatedly remember our self, our past, through representations and material things, i.e. representations that are not fully tied to the object, and objects that are not identical to their representation. Our closets, garages, and attics contain boxes of memories of different parts of our lives, items by which we want to be remembered when we are gone, or which are kept because they are connected to others now lost (cf. Hallam \& Hockey 2001; J. Assmann 1999a, 33f). This desire for connection, the memorial trigger, gives access to the past by actually obscuring the original object. The object acts as a go-between that mediates between past experiences and the present. But this is not only the case on a subjective level. Many of our institutionalized ways of collecting originates in the desire to make visible the invisible dimension of the in-between (Redin $2011,100)$. Objects are withdrawn from the world, only to re-enter it with a new set of meanings. They are (re)presented not only for what they once were, but for the extra-material qualities that turn them into present objects, regardless of their date of origin. As pointed out by the historian Krzysztof Pomian, such objects convert into 'semiophores', reaching a meta-functional level where their existence depends on the production of meaning (Pomian 1998, 49ff). Collectors' items or ancient objects exhibited in public museums, especially the kind of artifacts once linked to a certain utility value, are typical examples of such converted semiophores.

If we can claim that a medieval spoon ending up in a museum is no longer just a spoon, it is not merely because of the temporal distance between the 
object and its observer, but also because of the functional distance between the object's past and its present. The relation between history and representation is always caught within an economy of mediation. The museum, as an institution, is often thought of as a sort of time capsule, although its inventory will always continue to produce new meanings (Redin 2011, 101ff). It is equally inclusive and exclusive, mixing static time with dynamic time just as memory relates to forgetting. What we see in exhibitions or public collections are usually scenes arranged or reconstructed from a much larger inventory that remains hidden beneath the public space. The heart of the museum is not its exhibitions but its depository, often located underground in tempered rooms, where artifacts serve as representatives of different historical concerns.

The depository is a late version of the crypt, not only in the typical sense of catacombs and relics in Romanesque churches, but rather as an architectural internalization of the crypt's conceptual energy, its 'special kind of unconscious' as Abraham and Torok maintain. What comes into play is the constructive tension between objects 'at rest' (in suspension, repositorydwelling) and those exhibited. The rationality of the disposition is as strange and uncanny as the cemetery: the being there of all that is not here anymore. However, the museum is not a 'live burial' of introjective objects, and it is not necessarily a cemetery with artifacts exhibited on a lit de parade. On the contrary, it is consumed in the auratic gleam of the fetishized mediators. By entering one may feel 'closer to history'; but history is not open for revisiting, it is encrypted and reinstalled in an imaginative space. (Redin 2011, 103.)

\section{Myth as Encryption}

We now need to shift focus from the imaginative space created by 'histori$\mathrm{cal}^{\prime}$ artifacts to a narrated space of imagination that rather seems to conceal such historical and artificial dimensions of human experience.

If the crypt, in all its topicality, marks the attempt to hide something by using it as a strategic basis for something else, encryption is the temporal extension of the crypt. Instead of providing the basis of a strategy, it becomes part of a strategy of perpetuation. This strategy, however, does not merely conceal a previous message, but rather turns the previous message into a new one through a redirection of its force. Encryptions are thus parasitic, in the sense that they always require a host to be mutually concealed and exploited. Some of the cases touched upon above are perhaps all too obvious: the transmission of Christian customs through the transformation of 
pagan customs, which can be said to 'encrypt' places, objects, and practices by simultaneously hiding and disclosing them. These cases are often so closely linked to ecclesiastical politics and missionary strategies as to make them less relevant for our purposes here. If the tactical reasons for encryption are so clearly explicit, can we really claim that something needs to be decrypted by the contemporary scholar? A similar problem arises when we consider intentional secrecy, which of course can play a prominent role in religious activities. Things done and said in secret, within the closed circle of a secret society, are always perceived and presented as such both by initiated members and by those from whom the secrets are overtly kept hidden. It seems necessary to distinguish such cases of overt secrecy from the processes discussed here, because the encrypted aspects of culture are never presented in terms of what they keep hidden. When it comes to spoken and written discourse, for instance, we have to assume that certain tacit (or implicit) aspects of a message can go beyond that which others are already supposed to know, as well as that which lies hidden beneath a coded message. One such outcome of encryption is the genre commonly referred to as 'myth'.

A common denominator of myths is their propensity to conceal two facts about their origin and originality: 1) that they are based on earlier statements and 2) that they are party statements. An encrypted statement does not reveal its own historicity, nor does it take the form of a supposition marking the starting point for further investigation, what a scholar would call a conjecture or a hypothesis. The conceptual history of Greek hupóthesis is actually quite illuminating in this regard. The literal sense of the term is the placing under (hupotithemi) of something. We thus suppose, propose, or surmise (i.e. hypothesize) in the absence of evidence or a previous statement of fact, because we do not yet know for sure. The representation of a form or previous statement may be a likewise legitimate endeavour on the condition that it acknowledges its model. The ancient Greeks considered artistic imitation (mimêsis) to be a potentially worthy act as opposed to the unworthy act of metáthesis (a transposition or placing between), which was rather conceived as a deceptive claim on true originality. With this view on eloquence, mímêsis could be opposed to metáthesis in the specific sense of plagiarism. ${ }^{7}$ The horizontal opposition between mimêsis and metáthesis, between two forms of representation that either acknowledge or conceal their precedent, is thus vertically opposed to the supposition without a

7 . Cf. Demetrius, De elocutione, 112. 
precedent: the hupóthesis. If we extend the concept of plagiarism to include something less deceptively conceived, myth can be placed on an equal footing with metáthesis. It is the encrypted story already told, a story concealing its own historicity and plasticity through endless permutations of human interest, and insofar as another version is acknowledged it is always the false version of 'others', as opposed to our own, which is the correct one. A telling example of this situation is the great abundance of similar myths in the ancient Greek world that often seem to represent local variants of the same story, despite a common claim on veracity.

The traditional understanding of myth (in the sense of 'traditional story') subsumes the notion of a time and place beyond the regular contingencies of human interaction. Nevertheless, the present always has to be present in its absence, because myths are conceived of as being normative with regard to the present so as to evoke a social response, yet without referring overtly or exclusively to the current time and place. When Roland Barthes, in the 1950s, introduced myth as an analytical tool in his critique of contemporary politics, popular culture, and advertisement, he was apparently less interested in developing the traditional understanding of myth (Barthes 1972). His point of departure was rather the colloquial sense of 'false belief'. Nevertheless, since the concealment of historicity reappears in his attempts to grasp the essential mechanisms of contemporary myths, the gap between the different meanings of myth suddenly disappears. Whether we consider ourselves historians of religions or critics of modern capitalist society; we are still supposed to read these stories as partial reflections and transfigurations of a different and much more comprehensive story, not just as misrepresentations of reality. Whether or not they are believed to be true, something is constantly at work within myths that cannot be fully acknowledged. Unlike allegories and secret messages, which always provide the qualified reader with a key, myths conceal what they are and disclose what they are not. They prescribe what they claim to describe, copy what they claim to invent, and encrypt the past from which they seek shelter.

\section{Concluding Remarks}

This article reflects an initial and experimental phase in an ongoing research. Our point of departure was the burgeoning field of cultural memory studies, which has created an important platform for interdisciplinary historical endeavours in the humanities. This discussion is inextricably related to the study of religion, because it focuses on the intercultural means by which 
human populations engage symbolically with their own past. Since these means of symbolic engagement usually involve both a reinterpretation and a recapitulation of past events, it would be grossly misleading to assume that a past enmeshed in cultural interest is either merely unravelled or invented. What we have sought to elaborate upon further in the preceding paragraphs, however, does not so much concern the interested selectivity behind the more prominent cultural memory systems, but rather certain less recognized dimensions of cultural memory involving strategic displacement, implicitness, and indirect mediations.

We have tried to integrate two ways of approaching the concept of the crypt in order to reach the deep dimensions of cultural memory. On the one hand, we have drawn attention to the institutionalized practice of encryption in some historical contexts. On the other hand, we have allowed the psychoanalytical notion of repression to serve as a tool for understanding this deep dimension. Our ambition in this latter regard has been purely analogical.

We are convinced that this approach can favour the comparative study of religion. One evident example concerns the differentiation between religious processes grounded in systematic oppression (structural intentions) and those related to repression and oblivion, i.e. processes situated beyond any intentional means to eradicate memory. In other words, we need to avoid the risk of confusing political and anthropological situations of encryption. Although these situations may overlap to some extent, the distinction is of crucial analytical importance. Are we dealing with obsolete aspects of culture consciously maintained as hidden sources of attraction - usually in so-called top down situations - or with unreflective behavioural scripts that govern certain collective actions?

The identification of crypts and encryptions is not just any disclosure of a forgotten past. Archaeologists and historians may look for things forgotten and filed away, but not necessarily for indices of encryption. They need not identify a parasite to acquire adequate information. To remove things from the crypt in an act of decryption rather implies the counteraction of gradual concealment. These processes of gradual layering are not natural in the concrete sense of physical sedimentation or disintegration, nor are they always cultural in the sense of an active concern to destroy or keep things hidden. Encryptions may also respond to certain forms of cultural inadvertence. They result from failures of preservation and annihilation that keep certain aspects of the past in a state of uncertain belonging. If not for these failures, how else could they be detected? 


\section{Bibliography}

\section{Abraham, Nicolas \& Maria Torok}

1986 The Wolf Man's Magic Word. A Cryptonomy. Trans. by Nicholas Rand. Minnesota: Minnesota University Press.

1994 The Shell and the Kernel. Renewals of Psychoanalysis Vol. 1. Trans. by. Nicholas Rand. Chicago: Chicago University Press.

\section{Assmann, Aleida}

1999 Erinnerungsräume. Formen und Wandlungen des kulturellen Gedächtnisses. München: Beck.

\section{Assmann, Jan}

1995 Collective Memory and Cultural Identity. - New German Critique, 65 (Spring-Summer), 125-33.

1999a Das kulturelle Gedächtnis. Schrift, Erinnerung und politische Identität in frühen Hochkulturen. München: Beck.

1999 b Krypta - Bewahrte und verdrängte Vergangenheit. Künstlerische und wissenschaftliche Exploration des Kulturellen Gedächtnisses. - Bernhard Jussen (ed.), Archäologie zwischen Imagination und Wissenschaft. Anne und Patrick Poirier, 83-99. Göttingen: Wallstein.

2008 Communicative and Cultural Memory. - Astrid Erll \& Ansgar Nünning (eds), A Companion to Cultural Memory Studies, 109-18. Berlin \& New York: De Gruyter.

\section{Assmann, Aleida \& Jan Assmann (eds)}

1983 Schrift und Gedächtnis. München: Wilhelm Fink.

\section{Barthes, Roland}

1972 Mythologies. Trans. by Annette Lavers. London: Cape.

\section{Benveniste, Émile}

1969 Le vocabulaire des institutions indo-européennes 2: Pouvoir, droit, religion. Paris: Les éditions de minuit.

\section{Clauss, Manfred}

1990 Mithras: Kult und Mysterien. München: Beck.

\section{Connerton, Paul}

1989 How Societies Remember. Cambridge: Cambridge University Press.

2009 How Modernity Forgets. Cambridge: Cambridge University Press.

\section{Derrida, Jacques}

1986 Fors: The Anglish Words of Nicolas Abraham and Maria Torok. Nicolas Abraham \& Maria Torok, The Wolf Man's Magic Word. A Cryptonomy, xi-xlviii. Trans. by Nicholas Rand. Minnesota: Minnesota University Press. 


\section{Espositio, Elena}

2002 Soziales Vergessen. Formen und Medien des Gedächtnisses der Gesellschaft. Frankfurt am Main: Suhrkamp.

\section{Fentress, James \& Chris Wickham}

1992 Social Memory. New Perspectives on the Past. Oxford: Blackwell.

\section{Halbwachs, Maurice}

1992 On Collective Memory. Trans. by Lewis A. Coser. Chicago: Chicago University Press.

Hallam, Elizabeth \& Jenny Hockey

2001 Death, Memory and Material Culture. Oxford: Berg.

Hanson, R. P. C.

1978 The Transformation of Pagan Temples into Christian Churches in the Early Christian Centuries. - Journal of Semitic Studies 23, 257-67.

\section{Kuhn, Adalbert}

1864 Indische und germanische Segenssprüche. - Zeitschrift für vergleichende Sprachforschung 13, 49-74, 113-57.

\section{Pomian, Krzysztof}

1998 Der Ursprung des Museums. Vom Sammeln. Trans. by Gustav Rossler. Berlin: Wagenbach.

\section{Redin, Johan}

2011 Social Dreams of History: Museum, Utopia, Mythology. - Hans Ruin \& Andrus Ers (eds), Rethinking Time: Essays on History, Memory and Representation, 97-108, Stockholm: Södertörn Philosophical Studies. 